ZÖR 62 (2007), 237-258

DOI 10.1007/s00708-007-0177-2

Zeitschrift für

(C) Springer-Verlag 2007

öffentliches Recht

Printed in The Netherlands

\title{
The Case for a European Senate. A model for the representation of national parliaments in the European Union
}

\author{
Gerhard van der Schyff and Gert-Jan Leenknegt, Tilburg*
}

\author{
I. Introduction \\ II. From double to triple democratic legitimation \\ III. Senates in general \\ IV. Characterisation of senates \\ V. Powers of a European senate \\ VI. Composition of a European senate \\ VII. Conclusion
}

Keywords: European Senate; European Union; European Constitution; South African National Council of Provinces; comparative federalism; comparative constitutional law; bicameralism; democratic legitimacy; democratic deficit.

Legal provisions: German Basic Law (1949); Indian Constitution (1950); South African Constitution (1996); Treaty Establishing the European Community; Treaty Establishing a Constitution for Europe.

\section{Introduction}

The troublesome ratification process of the Treaty Establishing a Constitution for Europe (Constitutional Treaty) has laid bare the undeniable fact that European integration is going too far, and too fast, for a large part of the European population. In this regard it is often said that the European Union (EU) suffers from a democratic deficit - integration moves ahead while lacking democratic legitimacy.

* Lecturer and Senior Lecturer respectively, Department of Constitutional and Administrative Law, Faculty of Law, Tilburg University, The Netherlands. 
In addressing this problem the plea for strengthening the role of national parliaments within the EU has gained popularity in recent years. ${ }^{1}$ Members of national parliaments should be better informed on European policy, and parliaments should be involved in the policy-making process at Community level at an early stage, so that they would be able to play a much more active and leading role. This, in turn, would lead to a greater understanding and involvement among citizens, and to the strengthening of European democracy. Various suggestions have been made in this regard, including to explicitly grant national parliaments 'the subsidiarity test' regarding EU legislative proposals, as laid down in the First and Second Protocol attached to the Constitutional Treaty, as well as to make the European Commission accountable to national parliaments. Voices are also heard advocating the creation of an additional chamber, a 'European Senate', next to the European Parliament representing national parliaments. ${ }^{2}$

In this contribution we wish to state the case for introducing one such proposal, namely a senate, as we believe that this would increase the Union's democratic vitality, thereby making a dent in the democratic deficit it experiences at present. The attention is first turned to exploring the EU's democratic legitimacy, after which the focus falls on characterising the composition and competence of a possible senate. Other suggestions on the strengthening of national parliaments within the EU will also be discussed and highlighted, where apt, to illustrate their relation to a senate.

\section{From double to triple democratic legitimation}

Democracy in its purest form means that the people should govern themselves. In other words, citizens participate directly in the taking of political decisions that concern them. Those governed and their governors are thus one

${ }^{1}$ Cf Niblock, The EEC: National Parliaments in Community Decision-Making (1971); Weber-Panariello, Nationale Parlamente in der Europäischen Union (1995); Laursen/Pappas (eds), The Changing Role of Parliaments in the European Union (EIPA 1995); Smith (ed), National Parliaments as Cornerstones of European Integration (1996); Maurer/Wessels (eds), National Parliaments on Their Ways to Europe: Losers or Latecomers (2001); Kiiver, The National Parliaments in the European Union (2005).

2 The creation of a senate was first proposed in 1953, the failure of the European Defence Community put paid to any such plans. Calls have been made at various intervals since then for the creation of an additional legislative chamber, such as that in 1989 by former British Deputy Prime Minister Michael Heseltine, and more recently by former French Prime Minister Jospin, former German Foreign Minister Fischer and British Prime Minister Blair regarding the need for an extra body to be created in order to represent national parliaments. Cf A Second Parliamentary Chamber for Europe, Seventh Report by the EU Select Committee of the House Lords (2001); A European Second Chamber, Report by the French Senate (1999); Kiiver, The National Parliaments in the European Union (note 1) 127-128, for overviews and discussions. 
and the same, thereby lending legitimacy to the exercise of power and authority. This ideal is, however, all but possible in the smallest and most simple of societies. Large and complicated societies have to dilute this link between the governed and their governors for the sake of expediency. Democracy, in real terms, is therefore not so much direct as it is indirect. People are governed by representatives who are given a mandate to legislate and decide on behalf of the majority, instead of requiring the people to take all decisions themselves. This is especially true, and necessary, where the EU is concerned - as was also recognised in the Constitutional Treaty. ${ }^{3}$ Traditionally representative democracy in the EU rests on two pillars, or what can been termed double legitimacy. ${ }^{4}$ The first pillar being the Council of the European Union (Council of Ministers), as the voice of national governments; and the second pillar being the European Parliament, as the elected voice of all Europeans.

Although representative democracy is indeed an EU premise, it is in danger of being diluted to a mere slogan. An entity as large and complex as the EU is often accused of negating the link between the governed and those who are entrusted with governing them. As a matter of fact, increased frustration has been brewing against this form of representative democracy for a number of years, if not from the very beginning. ${ }^{5}$

The process of European governance and integration is seen as first and foremost a concern of the European political elite and national governments. National parliaments are mostly observant and react instead of act, while the average citizen is, at best, hardly interested, or plainly negative towards Europe. The gap between the citizen and the national state opens into an even deeper and wider chasm regarding Brussels. The EU is widely associated with expensive bureaucracy, a tendency to produce petty regulations on any conceivable subject, a lack of transparency and democratic control, and the loss of political and economic autonomy to the advantage of new member states. In this view, European integration is an autonomous and uncontrollable process, propelled by an unknown force. Such negative perceptions of the state of European democracy are only fuelled by charges that the European Parliament cannot effectively monitor other EU organs to the extent that the legislative function of the Council of Ministers actually escapes proper control and lacks a counter-weight. This only enhances the power of governments working through it while placing the role of legislators on the backburner. ${ }^{6}$ Concerns have also been voiced that the Euro-

3 Art I-45, I-46 of the Constitutional Treaty.

${ }^{4}$ Barents, Een Grondwet voor Europa (2005) 21.

5 Cf Blondel/Sinnott/Svensson, People and Parliament in the European Union: Participation, Democracy and Legitimacy (1998) 2-4, who argue that the European Community was always organised in an elitist manner, that saw democratic elements introduced here and there to keep the process within vague democratic parameters.

${ }^{6}$ Harlow, Accountability in the European Union (2002) 79. 
pean Parliament has not assumed the powers transferred by national parliaments to national governments when it comes to Europe. ${ }^{7}$ In other words, executive power is thus quite strongly represented at European level, but this is not counter-balanced by legislative control, thereby removing Europe even further from Europeans. The vision that national parliaments had to control their governments when it comes to EU matters has also come under pressure, as much as the idea that EU institutions had to be controlled by the European Parliament. For instance, national parliaments have on the whole been quite slow and reluctant to scrutinise Community developments ever since moves to European integration started in the $1950{ }^{\prime}{ }^{8}{ }^{8} \mathrm{Ex}$ ecutive wisdom in charting the future of Europe cannot substitute the need for democratic legitimacy.

To be fair though, the Community initially took decisions by consensus and enjoyed relatively limited competence. As national sovereignty was not threatened, so did populations and national parliaments not act. This however gradually changed with moves towards greater integration. Not only was the Community's power growing, but national governments could be outvoted in the Council of Ministers. National unease only increased after the adoption of the Single European Act in 1986. ${ }^{9}$ The first major revision of the Treaty of Rome that extended qualified majority voting to more areas, formalised European Political Cooperation and saw the goal set of a single market by 1993 . As with most things, every action is met by a reaction. 'More Europe' led to calls for more democratic control of Community empowerment. A need, as explained, not always met by the European Parliament. ${ }^{10}$ Interestingly, even though the European Parliament has been directly elected since 1979, citizens increasingly sceptical of integration identified more with national parliaments - a situation somewhat contradictory to the Tindemans Report that in 1975 viewed direct elections as a panacea for the Community's legitimacy ills. A case of favouring national institutions

7 Cf Harlow, Accountability in the European Union (note 6) 79; Jurgens, A Federal Option for the European Community or a Permanent Democratic Deficit, in Flinterman/Heringa/Waddington (eds), The Evolving role of National Parliaments (1994) 85-86; Gustavsson, Preserve or Abolish the Democratic Deficit, in Smith (ed), National Parliaments as Cornerstones of European Integration (1996) 100-123.

8 Raunio/Wiberg, Does Support Lead to Ignorance? National Parliaments and the Legitimacy of EU Governance, Acta Politica 2002, 147-148; Norton, National Parliaments in Western Europe, in Smith (ed), National Parliaments as Cornerstones of European Integration (1996) 22-23.

9 Raunio/Wiberg, Does Support Lead to Ignorance? National Parliaments and the Legitimacy of EU Governance (note 8) 147; Kiiver, The National Parliaments in the European Union (note 1) 14; Norton, National Parliaments in Western Europe (note 8) 23-27; Smith, EU Legitimacy and the 'Defensive' Reaction to the Single European Market, in Banchoff/Smith (eds), Legitimacy and the European Union: The Contested Polity (1999) 27-45.

${ }^{10}$ Blondel/Sinnott/Svensson, People and Parliament in the European Union: Participation, Democracy and Legitimacy (note 5) 4. 
with an indirect role, but closer to home as it were, to a directly elected European institution perceived as remote. This contradiction served as the catalyst in elevating the role and status of national parliaments in Community matters, both on a national and European level. At national level, for example, a number of constitutions, notably those of Germany, Portugal and France, were amended to increase the role fulfilled by national parliaments in scrutinising European legislation. With a similar courtship taking place at European level since the early 1990's, as highlighted in the introduction and elaborated on below. A clear indication that all is not well with the state of the EU's democratic legitimation, while the key may lie in rethinking the role of national parliaments.

As a matter of fact, it may be questioned whether the traditional approach of double legitimacy is not to be replaced by triple legitimacy. In other words, formal recognition of national parliaments as the third and direct mainstay of European democracy. Instead of often little more than implying a role for national parliaments at European level, and an indirect role at that, while viewing the Council of Ministers and European Parliament as the EU's main democratic actors. This question warrants attention, as double legitimacy simply amounts to a vanguard action that still fails to 'bring democracy home', a point well stressed by popular antagonism at the Constitutional Treaty culminating in its referenda defeats in France and the Netherlands. ${ }^{11}$ The time has come to shed the paternalist traits that have shadowed the Community ever since its inception and that often sees citizen consultation as a 'necessary evil' as it were. ${ }^{12}$ The European project is too important not to consult and heed the very Europeans it seeks to benefit.

By extending the base on which democratic legitimacy rests along the line of triple legitimacy, the bond between citizens and their rulers could be strengthened. It is in this context that the introduction of a senate must be understood and evaluated. Namely, as an instrument that seeks to enhance representative democracy by consolidating the role of national parliaments, thereby winning ground on the EU's democratic deficit in the quest for legitimacy. But what is meant by a senate, what should it do and what should it look like? These questions are addressed below.

\section{Senates in general}

The term 'senate' covers a broad variety of institutions. Even within the bicameral parliamentary systems in the EU, many differences can be found with

${ }^{11}$ Cf Nijeboer, The Dutch Referendum, 1 European Constitutional Law Review 2005, 393-405.

12 Blondel/Sinnott/Svensson, People and Parliament in the European Union: Participation, Democracy and Legitimacy (note 5) 3. 
respect to the functions, composition, and powers of institutions called 'senate'. ${ }^{13}$ The senate is therefore an institution which 'eludes uniform characterization'. ${ }^{14}$ Nevertheless, we must attempt to sketch the most important functions of senates, as the function a senate has in a certain political system is decisive, both for its manner of composition, and for the powers it should have. Subsequently, we will relate these functions to our discussion of a European Senate.

The cardinal question in this regard is, what is the raison d'être of the senate in political systems? Essentially, senates function as an instrument with which to legitimate political power. However, this is done by senates providing an additional form or route of representation to the usual or current means of representation. This is why senates are often referred to as 'second chambers', as they augment the existing or primary chamber in legitimating the exercise of power. In providing such representation senates usually defend particular interest groups, such as social or geographical units, and are called upon to co-decide the desirability or quality of legislative proposals in order to strengthen the political process. In short, senates serve to add legitimacy to a system by broadening its base of representation and checking power in order to increase the system's support or stability.

For example, traditionally senates were constructed in some older European democracies as a bulwark or stronghold of the Throne. ${ }^{15}$ In those cases, the loyal and conservative nobility, often appointed to the senate by the King himself, served to protect the King and his government against an overzealous lower house, governed by unrest and excitement. In those systems, the senate served mainly to protect the interests of the King and of the aristocracy against the lower house. However, due to the democratisation of parliaments in Europe in the course of the 19th century, which affected not only the lower houses, but also most senates, the role of senates has taken on a decidedly democratic flavour.

Senates are no longer the preserve of the privileged classes in adding their voice when it comes to legitimating political power. ${ }^{16}$ More often nowadays senates serve to represent the interests of sub-states within federations. As a matter of fact, one could say that 'bicameralism seems to be inherent to

${ }^{13}$ Cf Groß, Zwei-Kammer-Parlamente in der Europäischen Union, 63 Zeitschrift für ausländisches öffenliches Recht und Völkerrecht (2003) 32-50.

${ }_{14}$ Blom, Bicameralism - History - Theory - Problems, in Blom/Blockmans/de Schepper (eds), Bicameralisme: Tweekamerstelsel Vroeger en Nu (1992) 19. Cf Russell, Reforming the House of Lords (1999) 19-44.

15 Couwenberg, Bicameralism - Historical Background, Alternative Conceptions and Current Relevance, in Blom/Blockmans/de Schepper (eds), Bicameralisme: Tweekamerstelsel Vroeger en $\mathrm{Nu}$ (1992) 139-140.

16 With the exception of some chambers that still incorporate hereditary appointments, such as the House of Lords in the United Kingdom. Cf Russell, Reforming the House of Lords (note 14) 30. 
federalism'. ${ }^{17}$ In federations, senates provide a crucial second line of legitimacy to the political process. They help to strengthen the unity of the federation as they ensure the commitment of sub-state governments to federal policy, and, at the same time, are the expression of the autonomy of sub-states within the union. The classic example being the United States Senate that acts as a powerful voice in checking the power of the House of Representatives and giving sub-states a voice at federal level. Related to this federal aspect is the discussion on the meaning of bi-cameralism in view of modern multi-cultural and multi-ethnic societies. ${ }^{18}$ Even without a federal or strongly decentralised structure, a senate can still provide a platform for the specific interests of ethnic groups, as opposed to the general national interests on which the lower house generally focuses. ${ }^{19}$ In other words, senates can serve to represent geographical or social units. These may of course also overlap, as a particular territory, such as Wallonia in Belgium, may coincide with a particular identity or language. ${ }^{20}$

Currently, the function of a senate is increasingly linked to the need for precise and careful deliberation of bills and other parliamentary decisions. ${ }^{21}$ The task of a senate is to reconsider decisions taken by the government and the lower house from a more detached and non-political viewpoint. An argument related to this 'reflection'-theory concentrates on the monistic relation between the cabinet and the majority in the lower house that is often found in parliamentary systems. This monism can lead to a disregard of necessary parliamentary control over the government. Senates usually have a more dualistic stance against the government, and can consequently provide the necessary control over government more easily.

But where does this all leave national parliaments and the EU? Well, a senate would arguably be the ideal vehicle with which to realise triple legitimacy, as explained under the previous heading. A senate could function as a 'house of national parliaments' in providing a source of representation and legitimation within the EU in addition to the Council of Ministers and

17 Blom, Bicameralism - History - Theory - Problems (note 14) 30; Couwenberg, Bicameralism - Historical Background, Alternative Conceptions and Current Relevance (note 15) 139-146; Lijphart, Patterns of Democracy: Government Forms and Performance in Thirty-Six Countries (1999) 203.

18 Cf Couwenberg, Bicameralism - Historical Background, Alternative Conceptions and Current Relevance (note 15) 143.

19 E.g. s. 331 of the Indian Constitution (1950) provides that the President may, if he is of opinion that the Anglo-Indian community is not adequately represented in the Lok Sabha (the second chamber), nominate not more than two members of that community to it. Thereby ensuring adequate ethnic representation of Anglo-Indians.

20 Cf Craenen, Belgium, General Background and Legal Characteristics, in Craenen (ed), The Institutions of Federal Belgium: An Introduction to Belgian Public Law ${ }^{2}$ (2001) 2324.

21 Russell, Reforming the House of Lords (note 14) 21-22. 
European Parliament. A senate would be a prime means of aggregating the interests of and giving a voice to national parliaments, thereby ensuring an extra avenue of value articulation and democratic control when it comes to European affairs. In essence, its prime function would be to increase the EU's democratic input and broaden its base of appeal by housing national institutions as building blocks of its legitimacy.

However, having addressed a senate's general function, questions remain though as to the closer characterisation of its scope, and its relation to other legislative chambers. Only having addressed these questions can a clearer picture be given of the added value of a senate, especially in the European context.

\section{Characterisation of senates}

Senates have always met with criticism, to the extent that some countries have discussed the abolition of their senates, the Netherlands and Belgium for example. Some countries did actually abolish their senates, such as Denmark and Sweden after the Second World War. ${ }^{22}$ Most of the criticism addressed to senates concerns the alleged unnecessary repetition of procedures. When the cabinet and the lower house have agreed, often after lengthy debates, on a complicated compromise, the senate starts all over again to evaluate the problem at hand for a second time, usually adding no new significant insights to the matter. In that view, senates are simply a retarding element in the political process. On the other hand, senates are politically more independent from the government than their respective lower houses, which creates room for an independent judgement of matters. But when they do take a position which diverges from that of the lower house too often, they run the risk of being called 'obstructionist'.

Whether a senate can be criticised for being an unnecessary, retarding or even obstructionist element within the political system of course depends upon its composition and powers. When both houses of parliament have a similar or even identical basis of legitimacy - such as direct popular election - the need for reconsideration of bills and other decisions by a senate will be contested more easily. A senate will then simply be accused of amounting to needless duplication of an existing method of legitimation. In other words, a senate which has an apparent added value will be less sensitive to criticism. Thus, composing a senate by different means than the lower house will add to its value, as it brings an alternative means of legitimacy to the process. Lijphart calls this congruence. ${ }^{23}$ The more congruent chambers, the more

22 Russell, Reforming the House of Lords (note 14) 23.

23 Lijphart, Patterns of Democracy: Government Forms and Performance in Thirty-Six Countries (note 17) 207; Knippenberg, De Senaat: Rechtsvergelijkend Onderzoek naar het 
similar their composition, and the more incongruent the more dissimilar their composition.

Not only must senates, in order to be justified, add value as to their composition but also as to their powers. This is however a topic that lends to great controversy and division. For example, senates which have the power to reject bills without such rejection being subject to an override, or at least have the power to suspend them for a considerable period of time, will be more easily accused of impeding the political process than a weak senate which has little or no powers to do so. Yet, it makes very little sense, apart from window-dressing, to create a weak senate which is little more than a puppet or rubberstamp. Lijphart calls this symmetry. ${ }^{24}$ The more alike the powers of a senate in relation to the lower house the more symmetrical the relationship, and the other way round.

$\mathrm{Bi}$-cameral legislatures are then classified along a spectrum based on their congruence of composition and symmetry of power. ${ }^{25}$ For example, it is usually argued that strong bi-cameralism is found when a senate is incongruent and symmetrical, or nearly, in relation to the lower house. ${ }^{26}$ In other words, its composition differs from that of the lower house, but it is as powerful as the lower house. Bi-cameralism is therefore a strong and vivid reality, as the chambers enjoy different bases of legitimation, but possess evenly matched powers. Medium-strength bi-cameralism implies that the senate is congruent and symmetrical in relation to the lower house. ${ }^{27}$ Not only are their powers matched, but so too their composition, leading to a troublesome duplication of legitimacy. Medium-strength bi-cameralism is also to be noted when a senate is asymmetrical and incongruent. ${ }^{28}$ Not only is its composition then quite different from that of the lower house, but so too its powers. In other words, there is no duplication of legitimation, but the senate lacks somewhat in power. Whereas weak bi-cameralism is noted when a senate is composed similarly to its lower house, but guaranteed far less power - not only duplication of legitimation, but also less punch, as it were. ${ }^{29}$

House of Lords, de Sénat, de Eerste Kamer en de Bundesrat (Sdu Uitgevers 2002) 3. Cf Lijphart, Democracies: Patterns of Majoritarian and Consensus Government in Twenty-One Countries (1984).

${ }^{24}$ Lijphart, Patterns of Democracy: Government Forms and Performance in Thirty-Six Countries (note 17) 206; Knippenberg, De Senaat: Rechtsvergelijkend Onderzoek naar het House of Lords, de Sénat, de Eerste Kamer en de Bundesrat (note 23) 3.

25 Lijphart, Patterns of Democracy: Government Forms and Performance in Thirty-Six Countries (note 17) 212.

${ }^{26}$ E.g. Australia, Germany, Switzerland, United States. These, as well as the examples mentioned below, are taken from Lijphart, Patterns of Democracy: Government Forms and Performance in Thirty-Six Countries (note 17) 212.

27 E.g. Belgium, Italy, Japan, the Netherlands.

28 E.g. Canada, France, India, Spain, Venezuela.

29 E.g. Austria, Bahamas, Barbados, Ireland, Jamaica. 
Again, the question can be posed as to where this leaves national parliaments and the EU? The classification of senates according to their congruence and symmetry can obviously be useful in plotting and discussing the concept of a European Senate. These terms will then also be used in discussing the ideal powers and composition of such a body below. However, caution must be sounded in simply transplanting notions of strong to weak bi-cameralism to a European Senate. This is because such a body would function in a supranational and multi-level environment, as opposed to a national environment, the former being quite often different in form and theory to the latter. ${ }^{30} \mathrm{~A} \mathrm{Eu}-$ ropean Senate would also form part of what can at best be described as a multi-cameral structure, ${ }^{31}$ and not the usual bi-cameral structure on which the classification rests of senates being strong to weak. In other words, a European Senate must be justified and designed with a number of bodies in mind, and not only a lower house.

Yet, lessons may be drawn from senates in bi-cameral systems. For instance, incongruence as to its composition can be taken as desirable, in order to ensure that a senate provides an additional and different form of legitimacy, thereby adding value. It also to be remarked that a toothless senate would be more than undesirable, in other words there should be an effective measure of symmetry, but not so as to obstruct the political process. Ultimately the question is what constitutes an effective and worthwhile senate? Notions of strong and weak senates must be evaluated against this background, while still being sensitive to the European situation. This is precisely what is attempted below. The discussion will first turn to the powers of a European Senate, after which its composition will be discussed in this light.

\section{Powers of a European senate}

What should a senate do or be able to do? Its powers should obviously be related to its function, it would be counter-productive were a senate to stand loose from its purpose. Namely that of consolidating and enhancing the role and effect of national parliaments at European level in order to bolster the EU's democratic legitimacy.

${ }^{30}$ Cf Aroney, Federal Constitutionalism/European Constitutionalism in Comparative Perspective, in X. (ed), Getuigend Staatsrecht: Liber Amicorum A.K. Koekkoek (2005) 229-251; Schuitze, Co-operative Federalism Constitutionalised: The Emergence of Complementary Competences in the EC Legal Order, 31 European Law Review (2006) 167-184, on the institutional characterisation of the EU.

${ }^{31}$ Especially as the Commission may initiate legislative proposals, while the relation between the Council and European Parliament has itself been characterised as bi-cameral without the addition of a senate even having been considered. Cf Gro $\beta$, Zwei-Kammer-Parlamente in der Europäischen Union (note 13) 50-56; Couwenberg, Bicameralism - Historical Background, Alternative Conceptions and Current Relevance (note 15) 145. 
A senate's powers must clearly amount to an added value and not simply a duplicated value. Do its powers lead to the conclusion that it fulfils a different function to other organs, or does it amount to more of the same as it were without altering the situation? This is why senates, as mentioned, are generally chambers of reflection and revision, they hold the legislative process to account, instead of actively initiating the process. ${ }^{32}$ Senates are often designed to ensure the quality of the thought underlying proposed legislation and its possible impact, they essentially allow for the reconsideration of proposals and for the air to clear before finally coming to a decision. A good example in this regard would be the House of Lords in the United Kingdom, which can delay legislation, but cannot prevent its adoption. ${ }^{33}$

This argument implies that senates ought not have full or equal powers when compared to other legislative organs for fear of needless duplication. But not such a lack of power that sees it sidelined, thereby forsaking its function. This then also carries the gist of the main criticism levelled at bi-cameralism in Italy, both houses of parliament enjoy identical powers, thereby often leading to a needless ping-pong match and unnecessary deadlock, instead of ensuring meaningful addition to the legislative process. ${ }^{34}$ This is why constitutional designers often choose for senates to adopt a backseat, yet critical role when they participate in the legislative process and hold the executive to account. Yet, a senate must enjoy sufficient power to fulfil its function, although its function will usually be different from that of the other chamber or chambers it governs with. Symmetry of power should then be taken to mean enough power to meaningfully fulfil its function, what we can call real symmetry, instead of simply amounting to powers that are identical, what we can call formal symmetry.

This is exactly the measure to be used in determining the nature and extent of a European Senate's powers. It would be a waste of time and resources to create a chamber or organ that already exists, in other words simply repeating the Council of Ministers, European Parliament or Commission. What is called for is innovation not repetition.

To be honest though, it must be recognised that national parliaments are not completely left out in the cold at present. ${ }^{35}$ However, their influence, or power, can only be characterised as indirect and of an advisory nature, instead of direct and binding. For example, an assizes, or gathering, took place in 1990 between the European Parliament and national parliaments in order to dis-

32 Knippenberg, De Senaat: Rechtsvergelijkend Onderzoek naar het House of Lords, de Sénat, de Eerste Kamer en de Bundesrat (note 23) 4.

33 Cf Russell, Reforming the House of Lords (note 14) 12.

34 Cf Russell, Reforming the House of Lords (note 14) 139-140.

35 Cf Kiver, The National Parliaments in the European Union (note 1) 15-18; Raunio/ Wiberg, Does Support Lead to Ignorance? National Parliaments and the Legitimacy of EU Governance (note 8) 147-149. 
cuss the future of Europe. The idea of such gatherings was also included in Declaration 14, albeit non-binding, to the Final Act of the Intergovernmental Conference related to political unity, which eventually lead to the Treaty of Maastricht in 1992. A further declaration, also non-binding, similarly envisaged a greater role for national parliaments in holding the Community to account. Declaration 13 emphasised that national parliaments had to have greater access to EU documentation in order to aid ex ante scrutiny, although no time limits were set. In 1997 the ideas contained in Declaration 13 were formalised and became legally binding through the 'Protocol on the role of national parliaments in the European Union', which was attached to the Treaty of Amsterdam. National parliaments were granted a minimum of six weeks to scrutinise EU legislative proposals. However, the idea of regular gatherings, such as the Assizes of 1990, was not repeated. Instead Part II of the Protocol recognised the Conference of Community and European Affairs Committees (COSAC), which has been meeting twice yearly since 1989 and consists of national delegations and a delegation of the European Parliament that act as a forum for the exchange of information and which issues nonbinding statements. The trend of enhancing the role of national parliaments was carried through to the First Protocol of the Constitutional Treaty, which reaffirmed the right to information enjoyed by national parliaments when it comes to receiving EU documentation so as to assist them in controlling their governments. ${ }^{36}$

Groundbreaking though was the idea, also in the First Protocol, of granting national parliaments the power to test the subsidiarity of European legislative proposals. ${ }^{37}$ As mentioned, such proposals have to be sent to na-

36 According to Art 1-8 of the First Protocol, Commission consultation documents (green and white papers and communications) shall be forwarded directly by the Commission to national parliaments upon publication. The Commission shall also forward the annual legislative programme as well as any other instrument of legislative planning or policy to national parliaments, at the same time as to the European Parliament and the Council. Furthermore, draft European legislative acts sent to the European Parliament and to the Council shall be forwarded to national parliaments. The agendas for and the outcome of meetings of the Council, including the minutes of meetings where the Council is deliberating on draft European legislative acts, shall be forwarded directly to national parliaments, at the same time as to member states' governments. And finally, the Court of Auditors shall forward its annual report to national parliaments, for information, at the same time as to the European Parliament and to the Council.

37 The $2^{\text {nd }}$ para of Art 5 of the EC Treaty expresses the subsidiarity principle: 'In areas which do not fall within its exclusive competence, the Community shall take action, in accordance with the principle of subsidiarity, only if and in so far as the objectives of the proposed action cannot be sufficiently achieved by the Member States and can therefore, by reason of the scale or effects of the proposed action, be better achieved by the Community.' It is also laid down in Art I-11, Sec 3, of the Constitutional Treaty. For discussion of the principle in the EU-context, of Dehousse, Does Subsidiarity Really Matter? (1993); Estella, The EU Principle of Subsidiarity and its Critique (2002). 
tional parliaments, which can then review whether a proposal honours the principle of subsidiarity. Each national parliament is allocated two votes, or one vote for each chamber in bi-cameral parliaments. If a third of all votes reject a proposal with clear motivation for violating the principle of subsidiarity, the proposal must be reconsidered. This becomes only a fourth of all votes if the proposal is submitted by the Commission or a fourth of member states in accordance with article III-264 regarding freedom, security and justice. The initiator responsible for the proposal, be it the Commission, member states, European Parliament, Court of Justice, European Central Bank or the European Investment Bank must reconsider the proposal and may decide to retain, amend or withdraw the proposal, provided it motivates its stance. However, as the Constitutional Treaty has been defeated in the French and Dutch national referenda, thereby casting doubt on its future, it may be questioned when or whether anything will come of the proposals. Barroso, the current president of the Commission, has indicated his favour though in granting national parliaments the power to test for subsidiarity irrespective of the status of the Constitutional Treaty. ${ }^{38}$

Nonetheless, the proposed reform would function within the usual construction of double legitimacy. Although national parliaments would be granted a somewhat more direct role, they are arguably still very much portrayed as spectators or outsiders who can attract some attention, but who can do very little else. This construction does not officially recognise national parliaments as the third mainstay of European democracy. Not only may their envisaged role be too remote, their power to test legislative proposals for subsidiarity would still be non-binding; thereby, leaving national parliaments not much better off from where they started, institutions with essentially indirect and non-binding influence.

Whereas institutionalising, consolidating and expanding the power of national parliaments by means of a senate could serve to increase parliaments' direct and binding participation, not to mention increase the EU's democratic credentials. Yet, as explained, the touchstone for such a body's powers would have to be real symmetry aimed at its purpose of reflection and control, and not simply formal symmetry that would confuse its function. It would then arguably be a good idea to empower such a senate to effect control over the subsidiarity of legislative proposals, as foreseen in the Constitutional Treaty, while not allowing it to initiate legislation. The benefit being that national parliaments would so be accorded an organised and institutional voice at European level, but essentially in the role of national watchdog and not as supra-national initiator of legislation - a power common and essential to European organs in the strict sense of the word. This would be a good example

38 Speech held by Barroso, President of the European Commission, at the joint parliamentary meeting on the 'Future of Europe' on 9 May 2006. 
of healthy incongruence, by carving a niche for national parliaments without simply duplicating the function of other organs. Moreover, national parliaments represented in a senate could be strengthened in their role as watchdog by making it more difficult to override their objections to legislative proposals. In other words, incorporating a senate as an actual and real cog in the legislative process, but then in the role of reflection chamber, instead of active participant in bringing about legislation. For instance, it could be required that the organs responsible for adopting legislation would have to follow a more difficult procedure to adopt a proposal about which the senate had doubts as to its subsidiarity. ${ }^{39}$ A senate would then not be able to give a suspensive veto, but not an absolute veto. This would allow for it to question legislative proposals, but would at the same time allow for deadlocks to be resolved. Simply put, an additional democratic check, but then with a decidedly national flavour without derailing or frustrating the supra-national process as such. In this way the legislative process can be slowed down in order to allow for reflection, while also increasing its democratic input by forging a link with national representatives.

As a matter of fact, it may also be questioned why a senate should only exercise power in respect of the subsidiarity of legislative proposals, and not also in respect of proportionality. ${ }^{40}$ Not only would national parliaments then exercise control over the fact whether the EU assumed too much power, testing for subsidiarity in other words, but also on how the EU chooses to exercise its power, in other words in a proportional or disproportional way. This could have as positive consequence that the national level and supra-national level turn, or roughly turn, at the same speed when it comes to evaluating proportionality, thereby strengthening the legitimacy of EU legislation when it is to be implemented by national authorities.

As the aim is making the powers of national parliaments more direct and binding at European level, the question raises why this should only be in respect of legislative functions and not also in respect of executive functions? For example, why should a senate of national parliaments only exercise control over the Commission in respect of its legislative proposals, but not also in the way it executes its powers or is composed?

At present the President of the Commission is nominated by the European Council of Ministers and confirmed by the European Parliament. ${ }^{41}$ The President then nominates candidates as Commissioners, after which the Eu-

39 E.g. Peters, National Parliaments and Subsidiarity: Think Twice, 1 European Constitutional Law Review (2005) 72, also suggests a qualified majority, for example two thirds, in order to overturn the national parliaments' veto.

40 Art 5, para 3 of the EC Treaty reads: 'Any action by the Community shall not go beyond what is necessary to achieve the objectives of this Treaty.' Cf Emiliou, The Principle of Proportionality in European Law: A Comparative Study (1996).

41 Art 214 of the EC Treaty. 
ropean Parliament has to confirm the nominees as a group. The role set aside for national parliaments is therefore quite marginal. They can in theory influence their governments when it comes to the nominations they put forward, which is once again a decidedly indirect and advisory role. It is perfectly plausible that a senate could be given the same powers as the European Parliament in confirming the nomination of the President and his or her Commissioners. In this way national parliaments are not allowed to usurp the role of the European Parliament, as the directly elected voice of Europeans, but are themselves not sidelined in the process. This construction would also serve to enable national parliaments to speak for themselves. This is important, as parliaments are often more controlled by their governments than the other way round, making a mockery of parliamentary scrutiny of government input where Europe is concerned. ${ }^{42}$ The flipside of the coin being that national parliaments should then also be given the power to censure the Commission, similar to the European Parliament. ${ }^{43}$ It would make little sense for it to confirm nominations only then to be excluded from exercising any control over the very Commissioners it supported. Real symmetry would arguably coincide with formal symmetry in allowing national parliaments to scrutinise and control nominations to the Commission through a senate empowered to exercise the power of censure.

The above powers of a possible senate would fit well with its purpose, namely ensuring a more direct and binding role for national parliaments at European level, thereby augmenting the EU's democratic legitimacy, but without usurping existing structures. The idea would be to integrate national parliaments in the working of Europe, but with the emphasis on their exercising control and scrutiny from close quarters, instead of having them directing the process at the cost of better equipped European structures or allowing them to frustrate Europe without point.

It should be clear by now that not only must a delicate balance be struck as to the powers of a senate, but so must an even more delicate balance be struck as to its structure and composition to ensure that the vision of a senate does not simply float between good intentions and theory. The next section will address this very topic, what should a senate look like, and why?

\section{Composition of a European senate}

It should be clear by now that a European Senate should bring an added value to European democracy. It would not be meaningful to introduce such

42 Brown, National Parliaments in the Convention on the Future of Europe, paper 31/03, http://fedtrust.co.uk

43 Cf Corbett/Jacobs/Shackleton, The European Parliament ${ }^{6}$ (2005) 271-273, on the power of censure. 
an institution were it not to have a notable and worthwhile impact on European decision-making processes. One of the lessons drawn from the discussion of bi-cameralism above was that in terms of composition such an added value means that a senate may not be composed in an identical manner to the lower house. This would be valid not just in terms of mere numbers of seats or even the political colouring of those seats, but also with regard to the mechanism by which they are elected. In other words, an effective senate entails a measure of incongruence when it comes to its composition. Applied to the discussion we could say that a European Senate can only provide an additional third line of legitimacy if it has its own distinct power base. If its function is to embody an added value, its composition should reflect that function.

Several writers and commentators have pointed at existing European institutions and fora that could take on the function of a European Senate. The Council of Ministers has been suggested in this respect, but it does not fit our profile, simply because it does not represent national parliaments, but national governments. ${ }^{44}$ Therefore, it would not strengthen the legitimacy of European democracy by extending its base, as it would simply amount to reconfigurating existing EU structures.

COSAC has also been mentioned as a possible European Senate, most notably in a report by the French Senate in 1999. This forum, which consists of six members of each national parliament and six representatives from the European Parliament, although recognised in the 'Protocol on the role of the national parliaments in the European Union' attached to the Treaty of Amsterdam, has no official status as an EU institution. It would nonetheless be possible to transform COSAC into such an institution, simultaneously granting it explicit powers regarding the EU's legislative procedures. However, such an institution would not fit our profile of a European Senate very well. It would not be a permanent institution, but only a periodically convening forum, as the French Senate Report also suggested. ${ }^{45}$ It would be quite difficult though to perceive how such an institution could make a notable impact on European decision-making processes. For similar reasons, a Convention including representatives of national parliaments, such as the one convened to debate a constitution for Europe, or an Assizes of the national and European parliaments, which was convened in 1990 as a prelude to the Maastricht Treaty, is not suitable to serve as a European Senate either.

Giving effect to the envisaged powers of a European Senate, developed earlier in the discussion, requires a structural solution. Namely, a separate

${ }^{44}$ Cf Groß, Zwei-Kammer-Parlamente in der Europäischen Union (note 13) 50-56; Couwenberg, Bicameralism - Historical Background, Alternative Conceptions and Current Relevance (note 15) 145.

45 The Report suggested that such a body should have six sessions per year, each session lasting a day and a half. 
and permanent institution which has a distinct profile in relation to the existing organs, but then as the voice of national parliaments. That means one has to look beyond the existing institutions. So what should such a new European institution look like? Or rather, how should it be composed?

Numerous methods for the composition of senates can be found in parliamentary democracies. ${ }^{46}$ Firstly, there are senates appointed in some or other fashion. In Canada for example, the members of the Senate are appointed by the Governor General, on proposal of the Prime Minister. The Canadian Senate is generally characterised as enjoying low legitimacy, and consequently as being a rather weak senate, even though it has relatively strong formal powers. Its lack of legitimacy prevents it from using these powers in an effective way. However, appointed senates are not necessarily weak. Since 1958 the British House of Lords has consisted of hereditary peers and peers appointed for life, with an emphasis on life peers after the reforms of 1999. Appointments are made by the Crown, on proposal of the Prime Minister. The House of Lords also enjoys relatively low legitimacy as its membership is either by appointment or hereditary succession, but is nonetheless characterised by a high level of political and professional experience, making it a relatively strong senate, which can have considerable impact on the legislative process. ${ }^{47}$ The Federal Council of Germany (German Bundesrat) is also an example of an appointed senate, but it differs from the Canadian and British senates in one major respect. The Bundesrat is not appointed by the Federal President or Chancellor, but its members are selected from and by the governments of the Länder or federal regions. In other words, a 'bottom up' style appointed senate representative of regional governments, as opposed to the Canadian and British senates that are appointed by the central governments in a 'top down' fashion.

A form of 'top down' appointment is no realistic option as a mechanism for composing a European Senate. Who should be granted the authority to appoint the senators? The European Commission, Council of Ministers, or perhaps the European Council? Such a senate would be appointed by the very institutions it should seek to control, meeting with the same criticism regarding the lack of legitimacy as the British and Canadian examples. Furthermore, a senate should be independent from other EU institutions and, as argued here, serve to represent national parliaments. In order to do this, it must have its power base in those national parliaments. A consequence of this conclusion is that the German variance of 'bottom up' appointment will not suffice for a European Senate. Such a system would grant the appointment power to national governments, and not to national parliaments.

46 Cf Russell, Reforming the House of Lords (note 14) 29-32.

47 Knippenberg, De Senaat: Rechtsvergelijkend Onderzoek naar het House of Lords, de Sénat, de Eerste Kamer en de Bundesrat (note 23) 97-103; Shell, The House of Lords and the Thatcher Government, Parliamentary Affairs 1985, 16-32. 
Another problem would be presented were a senate to be composed through direct elections. A situation would so be created whereby a senate is identical, or at least very similar, in terms of its composition to the existing European Parliament. There are examples of such senates, for example Italy and Spain have senates which are composed, at least for the largest part, in a way similar to that of the lower house. ${ }^{48}$ In Spain, both houses of parliament are directly elected, though not in an identical way, a majoritarian system is followed for the Senate, while the lower house is elected on a proportional basis. But in both countries, the senate has a limited impact on the democratic process. ${ }^{49}$ Similarly, a directly elected senate would not have a distinct added value in terms of legitimacy, as it negates the lesson taught that incongruence serves to enhance a body's legitimacy by providing it with its own base.

An indirectly elected European Senate is conceivable though. National parliaments could be granted the power, after national parliamentary elections have taken place, to elect the members of a European Senate to represent their interests at European level. This would certainly meet the requirement of incongruence as regards to composition. This being the case as the Council of Ministers is designated by national governments and the European Parliament is directly elected by Europeans, while a European Senate would be indirectly elected by national parliaments. Care must be taken though in ensuring that in electing such a senate the voices of national parliaments do not get lost in the process. Some indirectly elected senates, such as those of the Netherlands and Ireland do not act as strong regional voices. Such senates then have to be justified in terms of their function as reflection chamber alone, and not also in terms of regional representation. As to a European Senate, the ideal balance would be struck by designing a chamber that allows room not only for reflection, but one that takes note of territorial representation.

In this regard, the South African National Council of Provinces (NCOP) poses an interesting model for a European Senate. ${ }^{50}$ The NCOP consist of 90 members, ten for each of South Africa's nine provinces. Of each group of ten representatives, six are permanent, and four are special delegates. The permanent members are designated by the provincial legislature, the four special delegates are the provincial prime minister, and three other members of the

48 Prakke/Kortmann (eds), Constitutional Law of 15 EU Member States (2004) 495-499, $757-763$.

49 Cf Russell, Reforming the House of Lords (note 14) 150-151.

50 Art 60-62 of the South African Constitution (1996). Rautenbach/Malherbe, Constitutional Law ${ }^{4}$ (2004) 124-125; Malherbe, The South African National Council of Provinces: Trojan Horse or White Elephant, Tydskrif vir die Suid-Afrikaanse Reg/Journal of South African Law 1998, 77-96; Murray/Nijzink, Building Representative Democracy: South Africa's Legislatures and the Constitution (Parliamentary Support Programme 2002) 41-58; Murray/Simeon, From Paper to Practice: The National Council of Provinces After its First Year, 19 SA Public Law (1999) 96-141. 
legislature, all three designated by the legislature. ${ }^{51}$ The delegates can also be members of the provincial executives, as they retain the membership of their provincial legislatures. The special delegates are designated in service of the specific expertise wanted in the NCOP at a given moment. Part of the inspiration for this construction is the German Bundesrat, but there is a significant difference: not the provincial governments, but the legislatures - the provincial parliaments - appoint the members of the NCOP.

A European Senate based on the South African model would have the advantage of providing a structural solution, in the sense that it would be a permanent institution, consisting of members of national parliaments, which would at the same time be perfectly shaped to equip itself with the specific expertise needed to provide scrutiny in various policy areas. Providing for permanent delegates with both a European and national mandate would ensure continuity and a steady link with national institutions. While the special delegate construction would allow members of national parliaments to be involved in the European democratic process without burdening them with a permanent double mandate, but only on occasion when their opinions or expertise is needed in the senate. This would be an ideal way in which to address the concern, as also expressed by the EU Select Committee of the House of Lords, that a permanent double mandate for all delegates would lead to a very difficult if not impossible workload. ${ }^{52}$ While also meeting the need identified by the French Senate, namely that Europe lacks the direct and visible input of prominent national parliamentarians, which could only serve to strengthen the legitimacy of European decision-making. ${ }^{53}$

As a matter of fact, such a construction would not be a complete novelty within the institutional structure of the EU. For example, the proposed model is reflected to some extent in the composition of the Council of Ministers, which is also an institution with a variable composition that is determined by the policy issues at hand. In addition, members of the European Parliament were not directly elected until 1979, but also designated by their national parliaments. Furthermore, double mandates were standard until that time, and still possible today. However, the construction is quite rare and discouraged even to the extent that some member states, such as Italy, do not allow simultaneous membership of their national parliaments and the European Parliament. ${ }^{54}$

This is where the added value of a European Senate constructed along the lines of permanent and special delegates becomes particularly clear. The directly elected members of the European Parliament can be allowed to devote

51 Art 60-62 of the Constitution of South Africa (1996).

52 A Second Parliamentary Chamber for Europe (note 2) part 4 (no 30).

53 A European Second Chamber (note 2).

54 Cf Van de Meerssche, Van Jalta tot Malta: Politieke Geschiedenis van Europa (1990) 188-190. 
their full attention and mandates to Europe, whereas an indirectly elected senate can be allowed to control Europe while not leading to excessive workloads for its members. National specialists on Europe can be given permanent double mandates, while special delegates can be appointed where and as needed.

But how should national parliaments be represented in a senate, and how should its voting be organised? Should national parliaments be afforded equal representation or proportional representation based on population numbers? As the idea is it to provide national parliaments with a voice it would seem logical to opt for representation based on parity and not proportionality, similar to the United States Senate. In this way all parliaments can have a say, thereby ensuring that smaller states do not have to be fearful of being drowned out. This will also ensure desired incongruency, as the principle of proportionality is respected in composing the European Parliament, while equal representation is also done justice, thereby allowing a distinct route of democratic legitimation to be developed. This does not mean to say though that equal representation may not be tempered somewhat, for example by allowing larger states twenty votes and smaller states ten votes, along the lines of the German Bundesrat. ${ }^{55}$ As long as the national parliaments of smaller states are not marginalised completely, as the proportional division of votes between Germany and Malta would have as effect.

Further as to representation, it would be apt for member states to decide themselves how to allocate their allotted votes in a senate to their national parliaments. For instance, bi-cameral parliaments, such as France, must be allowed to decide if and how their votes are to be divided between the chambers. While federal states, such as Belgium, should be able to decide whether the term 'national parliaments' includes votes being allotted federal territories and not only the federal parliament.

The same would go for voting procedures in a European Senate. States must be allowed to decide whether their senators must cast their votes as a group, in other words ten votes in favour or against, or whether senators may cast individual ballots. This would allow a uni-cameral parliament, such as that of Denmark, to speak with a unified voice, if it so desired, whereas bicameral parliaments or federal states would be allowed to account for different chambers or regions to state their views at European level.

In essence, composing a European Senate must be alive to the fact that it must strive for incongruence in relation to other European institutions, especially the European Parliament, in allowing national parliaments to be given a direct and distinct voice in making triple legitimacy a reality.

55 According to Art 51 of the German Basic Law (1949) each Land has between 3 and 6 members in the Bundesrat, depending on its number of inhabitants. Cf Prakke/Kortmann (eds), Constitutional Law of 15 EU Member States (note 48) 332. 


\section{Conclusion}

We believe that there are strong arguments in favour of the introduction of a European Senate. Such an institution would be a significant and meaningful addition to the EU institutional structure, as it would serve to strengthen the legitimacy of European democracy in the face of its democratic deficit - especially after the referenda rebellions against the Constitutional Treaty. A direct and binding involvement of national parliaments in European decision-making would provide a much desired third line of legitimacy. This then by expanding the usual and dated construction of double legitimacy based on the European Parliament and the involvement of national governments through the Council of Ministers.

A European Senate would also be the ideal vehicle with which to add tangible and organised value to parliamentary scrutiny within the EU. This would serve to improve the quality of European legislation and governance, but it would also be a crucial institution on a more abstract level. It could serve as a mechanism to represent both national interests at the European level and European interests at the national level by bringing national parliamentarians more in contact with Europe.

In designing such a body special inspiration can be drawn from bi-cameral legislatures when it pertains to its powers and composition. More concretely from the example set by the South African second chamber, the NCOP. The NCOP provides us with a promising model with which to shape a European Senate, as it would allow for a wide involvement of national parliamentarians at the European level by providing a continuous link between national parliaments and Europe, while at the same time providing the expertise needed at any given moment.

In essence, a European Senate, properly conceptualised and designed, would go a long way towards the ideal expressed by Joschka Fischer, then German Minister of Foreign Affairs, in May 2000 that the EU should be: 'A Europe of nation-states and a Europe of citizens. ${ }^{56}$

\section{Zusammenfassung}

Die beiden Autoren plädieren für die Gründung eines Europäischen Senats: Solch eine Institution würde eine signifikante und bedeutungsvolle Ergänzung zur institituionellen Strukture in der EU darstellen; als es dazu dient die Legitimität der Europäischen Demokratie, angesichts ihres Demokratiedefizits zu stärken; insbesonders nach der Rebellion qua den Referenden

56 Fischer, From Confederacy to Federation - Thoughts on the Finality of European Integration, speech held at Humboldt University in Berlin on 12 May 2000. 
gegen den Verfassungsvertrag. Eine direkte und bindende Beteiligung von nationalen Parlamenten an der europäischen Entscheidungsfindung würde eine viel geforderte dritte Linie der Legitimität liefern. Dies sodann durch Expansion der üblichen und überholten Konstruktion von doppelter Rechtmäßigkeit, basierend auf dem Europäischen Parlament und der Beteiligung von nationalen Regierungen durch den Ministerrat. Ein europäischer Senat wäre auch das ideale Vehikel, mit dem ein materieller und organisierter Wert zur parlamentarischer Prüfung innerhalb der EU hinzugefügt wird. Dies würde dazu dienen, die Qualität von europäischen Gesetzen und der Verwaltung zu verbessern, aber es wäre auch eine entscheidende Institution auf einer abstrakteren Ebene. Es könnte als Mechanismus dienen, um beides zu repräsentieren, nationale Interessen am europäischen Level und europäischen Interessen am nationalen Level; dadurch, indem nationale Parlamentarier mehr in Kontakt mit Europa gebracht werden. Beim Gestalten solch einer Institution kann spezielle Inspiration von der bikameralen Gesetzgebung geschöpft werden, wenn es um deren Kräfte und deren Komposition geht. Konkreter am Beispiel der südafrikanischen zweiten Kammer, des National Council of Provinces (Nationaler Provinzenrat). Das NCOP liefert uns ein vielversprechendes Modell, mit dem ein europäischer Senat zu formen ist, da es eine breite Beteiligung von nationalen Parlamentariern auf europäischem Level ermöglicht, indem eine fortlaufende Verbindung zwischen nationalen Parlamenten und Europa vorgesehen ist, während zu derselben Zeit jederzeit die erforderliche Sachkenntnis liefert. Im Kern, regelrecht konzeptualisiert und gestaltet, würde ein europäischer Senat einen langen Weg in Richtung des vom ehemaligen deutschen Außenminister Joschka Fischer im Mai 2000 ausgedrückten Ideals gehen, das die EU sein sollte: Ein Europa von Nationalstaaten und ein Europa von Bürgern.

Correspondence: Dr. Gerhard van der Schyff and Dr. Gert-Jan Leenknegt, Department of Constitutional and Administrative Law, Faculty of Law, Tilburg University, P.O. Box 90153 , 5000LE Tilburg, The Netherlands, e-mail: G.vdrSchyff@uvt.nl, G.Leenknegt@uvt.nl 